\title{
The effect of an educational program using the educational module on learning some basic skills of gymnastics for first grade students of the primary school Shimaa Gamal Aldin Gaafar/* Dr
}

\section{Introduction\& research problem:-}

Physical education is considered strong part of the parties of general education and it is applied educational field which try to educate the individual practically a full education psychologically, socially and physically through the physical activity in order to produce the upcoming educational findings. It was necessary to provide the student with the perfect image in terms of training gradually and knowing the elements of the game completely and the suitable level for the grade of the student. This can achieve only if the teacher himself understand these activities in the way which allow him to help the student to acquire it.

The role of the educational programs appears in developing the basic skills as it is the main element which determine the path of action, achieve a specific goal in order to reach at the suitable level and ensure the success of the work accurately. (22: 9) (208: 16 ).

Module is a mini standard organizational educational unit located within a group of sequential units guaranteed by the organized educational program, arranged to achieve specific educational goals in order to help the learner to walk and success according to their capabilities and his speed under the supervision and guidance of a teacher. (152: 33).

The importance of module is because it is a mean to organize and follow the educational experience and the complete the scientific material perfectly with a less effort. It also reveals for the teacher the weaknesses of the learner during his study of Module, so that he can evaluates him (130: 36).

The main goal of education is to teach effectively; as teaching interacts with several major and minor variables such as the ways of learning and its methods and strategies which 
participate in its similar and different effects on teaching (14:3).

"Moussa Ibrahim," "Adel Hassan" (1994) " refer that gymnastics occupies an important place in public education programs and primary school especially in the most developed countries. These activities are often included within the activities of selecting the self capacity because of its many movements and skills in which the student competes with himself confirming himself (29:95).

This agreed with what " Edyl Shenoda", "Samya Mansour" (1999) and "Mohamed Shehata" assured that gymnastics depends on student's ability to perform difficult exercises and movements perfectly(7:38) (24:41).

Through what the researcher has seen from the previous studies, the reason of difficulty to learn gymnastics for the age stage (under consideration) is that the current educational programs don't take care with the qualitative exercises programs which develop those skills for students. The results of this study referred that the interest of those exercises will lead to increasing the skillful level; what motivate the researcher to procedure this study in order to identify the effect of an educational program using the educational module on learning some basic skills of gymnastics for first grade students of the primary school.

\section{Aim of the study:}

- There are Significant differences between pre and post measurement in the level of skillful variables for student of the control group.

- There are Significant differences between pre and post measurement in the level of skillful variables for student of the experimental group.

- There are statistically significant differences between the pre and post measurements in the skillful variables of the control and experimental groups in favor of the experimental group.

\section{Plan \& procedures:- Methodology:}

The researcher used the experimental method using experimental design of pre and post measurements on pre and post groups. 
Sample of the study:-

It has been selected by the random intentional way from primary forth grade students at the experimental school. There number was (40) female students. Also (16) female students have been selected randomly from research community to do the survey.
Steps of preparing the program:

- Determine the appropriate basic skills in gymnastics in that age stage.

- Identify the physical preparation exercises which will contained in the educational module.

- Identify the tools used in the educational module.

Results:-

\section{Table (1)}

\section{Significant differences between pre and post measurement in the}

level of skillful variables for student of control group $\quad \mathbf{N}=\mathbf{2 0}$

\begin{tabular}{|c|c|c|c|c|c|c|c|}
\hline \multirow[t]{2}{*}{$\begin{array}{l}\text { Skillful } \\
\text { variables }\end{array}$} & \multicolumn{2}{|c|}{$\begin{array}{l}\text { Pre- } \\
\text { measurement }\end{array}$} & \multicolumn{2}{|c|}{ Post-measurement } & \multirow{2}{*}{$\begin{array}{l}\text { Differences } \\
\text { between } \\
\text { averages }\end{array}$} & \multirow[t]{2}{*}{ improvement } & \multirow[t]{2}{*}{ (T)value } \\
\hline & SMA & $\begin{array}{l}\text { Standard } \\
\text { deviation }\end{array}$ & SMA & $\begin{array}{l}\text { Standard } \\
\text { deviation }\end{array}$ & & & \\
\hline $\begin{array}{l}\text { Front } \\
\text { high } \\
\text { balance }\end{array}$ & r.vo & .00 & 0.0. & $.9 T$ & 1.10 & $\% \leq 7.77$ & T.VV \\
\hline $\begin{array}{l}\text { Hand } \\
\text { standing- } \\
\text { Dome }\end{array}$ & r. $\leqslant 0$ & . & $0 . \Sigma \wedge$ &. .11 & $r . . r$ & $\% \circ \wedge . \wedge \varepsilon$ & T.A9 \\
\hline $\begin{array}{l}\text { Upgrading from } \\
\text { walking and } \\
\text { running to } \\
\text { perform } 1 / 4 \text { roll }\end{array}$ & r.t. &. .11 & $0.7 T$ &. ro & T.ET & $\%$ V0.7r & 9.79 \\
\hline $\begin{array}{l}\text { Performing } \\
1 / 2 \text { roll into } \\
\text { air }\end{array}$ & r.7o &. $.0 T$ & $0 . V \varepsilon$ & 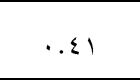 & $r . .9$ & $\% 0 V . r y$ & T.70 \\
\hline dome & r.r. & .19 & 0.79 & $.7 T$ & r.rq & \%VY.\&Y & T. $\varepsilon V$ \\
\hline $\begin{array}{l}\text { Hand } \\
\text { standing }\end{array}$ & r.lo & $.01 \varepsilon$ & $0.7 T$ &. ro & $Y . \varepsilon V$ & 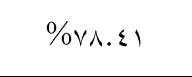 & T.70 \\
\hline split & r.70 &.$+T_{1}$ & 0.19 & $.1 \mathrm{~V}$ & T.TE & \%т1.r4 & r.Tr \\
\hline total & $r \leqslant .10$ &. $.0 \wedge$ & rq.os &. .79 & 10.19 & \%ur.vr & $r .91$ \\
\hline
\end{tabular}

The value of tabled $(\mathrm{t})$ at significant level $0.05=1.72$

Table (1) shows that there are statistically significant differences between the pre and post measurements in the skillful variables for the control group in favor of the post measurement; as table (T) was between 2.63 to 2,98 which

Assiut Journal For Sport Science Arts 
is higher than the value of tabled (T).

Table (2)

Significant differences between pre and post measurement in the level of skillful variables for student of control group $\quad \mathbf{N}=\mathbf{2 0}$

\begin{tabular}{|c|c|c|c|c|c|c|c|}
\hline \multirow[t]{2}{*}{ Skillful variables } & \multicolumn{2}{|c|}{ Pre-measurement } & \multicolumn{2}{|c|}{ Post-measurement } & \multirow{2}{*}{$\begin{array}{l}\text { Differences } \\
\text { between } \\
\text { averages }\end{array}$} & \multirow[t]{2}{*}{ improvement } & \multirow[t]{2}{*}{ (T)value } \\
\hline & SMA & $\begin{array}{l}\text { Standard } \\
\text { deviation }\end{array}$ & SMA & $\begin{array}{l}\text { Standard } \\
\text { deviation }\end{array}$ & & & \\
\hline $\begin{array}{l}\text { Front high } \\
\text { balance }\end{array}$ & r.VV & $\cdot r_{1}$ & 7.1. & $.0 T$ & t.rt & $\% \pi 1 . \wedge$. & r.V \\
\hline $\begin{array}{l}\text { Hand standing- } \\
\text { Dome }\end{array}$ & T.ET & .70 & T.YT &.$r_{7}$ & T.A. & $\% \wedge 1 . \wedge \vee$ & r.7o \\
\hline $\begin{array}{l}\text { Upgrading from } \\
\text { walking and } \\
\text { running to } \\
\text { perform } 1 / 4 \text { roll }\end{array}$ & T.MI & $\cdot .10$ & $7.1 \leq$ & $.0 \leqslant$ & r.9r & $\% 91 . r V$ & r.to \\
\hline $\begin{array}{l}\text { Performing } 1 / 2 \\
\text { roll into air }\end{array}$ & T.TT & .10 & 0.99 & .11 & t.re & $\% 70 .\{7$ & r.99 \\
\hline dome & t.rt & $\cdot \wedge 0$ & $7.1 T$ &. $.0 Y$ & r.^. & $\%$ \%乏.rT & r. $\varepsilon q$ \\
\hline Hand standing & r.lT &.$Y_{1}$ & 0.9. & .70 & r.VA & $\% \wedge$ \%.।. & $r .90$ \\
\hline Split & T.TT & .11 & 7.10 & . & r.or & $\% 79 . \wedge \wedge$ & r.乏l \\
\hline total & $r \varepsilon . \cdot \lambda$ & 1.57 & ET.TT &. $.9 \mathrm{~V}$ & $11.0 \varepsilon$ & $\% \vee 7.99$ & r.o. \\
\hline
\end{tabular}

The value of tabled (t) at significant level $0.05=1.72$

Table (2) shows that there are statistically significant differences between the pre and post measurements in the skillful variables for the

experimental group in favor of the post measurement; as table (T) was between 3.25 to 3.95 which is higher than the value of tabled (T).

Table (3)

SMA, standard deviation and Significant differences between pre and post measurement in the level of skillful variables for student of control and experimental groups $\mathrm{N}=\mathbf{4 0}$

\begin{tabular}{|c|c|c|c|c|c|}
\hline \multirow[t]{2}{*}{ Skillful variables } & \multicolumn{2}{|c|}{ Pre-measurement } & \multicolumn{2}{|c|}{ Post-measurement } & \multirow[t]{2}{*}{ (T)value } \\
\hline & SMA & $\begin{array}{l}\text { Standard } \\
\text { deviation }\end{array}$ & SMA & $\begin{array}{l}\text { Standard } \\
\text { deviation }\end{array}$ & \\
\hline Front high balance & 7.1. & $.0 Y$ & 0.0. & $.7 r$ & r.VA \\
\hline Hand standing-Dome & T.YY &.$Y 7$ & $0 . \leqslant \Lambda$ & .11 & T.TY \\
\hline $\begin{array}{l}\text { Upgrading from } \\
\text { walking and running }\end{array}$ & $7.1 \leq$ & $.0 \leq$ & $0.7 Y$ & r ro & r.os \\
\hline
\end{tabular}


to perform $1 / 4$ roll

\section{Follow Table (3)}

SMA, standard deviation and Significant differences between pre and post measurement in the level of skillful variables for student of control and experimental groups $\quad \mathrm{N}=40$

\begin{tabular}{|l|l|l|l|l|l|}
\hline \hline Skillful variables & \multicolumn{2}{|l|}{ Pre-measurement } & \multicolumn{2}{|c|}{ Post-measurement } & (T)value \\
\cline { 2 - 5 } & SMA & $\begin{array}{c}\text { Standard } \\
\text { deviation }\end{array}$ & SMA & $\begin{array}{l}\text { Standard } \\
\text { deviation }\end{array}$ & \\
\hline \hline
\end{tabular}

\begin{tabular}{|c|c|c|c|c|c|}
\hline $\begin{array}{l}\text { Performing } 1 / 2 \text { roll } \\
\text { into air }\end{array}$ & 0.99 &. .11 & $0 . V \varepsilon$ & $\because \varepsilon 1$ & r.). \\
\hline dome & 7.11 & $.0 Y$ & 0.79 & $.7 r$ & $r .91$ \\
\hline Hand standing & 0.9. & .70 & 0.74 &.$Y_{0}$ & $r . r_{1}$ \\
\hline split & 7.10 & .47 & 0.19 & $.1 \mathrm{~V}$ & $r .00$ \\
\hline total & $r \leq .7 T$ & $.9 V$ & ए $9.0 \leqslant$ & .79 & $T .7 \varepsilon$ \\
\hline
\end{tabular}

The value of tabled $(\mathrm{t})$ at significant level $0.05=1.68$

Table (3) shows that there are statistically significant differences between the pre and post measurements in the skillful variables of the control and experimental groups in favor of the experimental group; as the value of calculated $(\mathrm{T})$ was higher than the value of tabled $(\mathrm{T})$.

\section{Results Discussion:-}

Table (1) shows that there are statistically significant differences between the pre and post measurements in the skillful variables for the control group in favor of the post measurement; as table $(\mathrm{T})$ was between 2.63 to 2,98 which is higher than the value of tabled (T).

The researcher attributes these results to the traditional program using at the school. These results agree with the results of both "Ahmed Alhady Yousef Albadawy (1997) (4) and "Rehab Hafez"(2007) (10) which refer that the traditional program used with the control group in the study leads to improving the performance. The researcher believes that the regularity of the students at the control group in the study has a positive effect in those differences.

Also the style of teacher followed in implementing the educational method with its physical and kinetic exercises 
such as strength, speed and agility which have a main role in developing these characteristics thus the improvement of skillful performance.

The educational activity of the lesson is the basic of the study plan taken on by the teacher in order to learn the kinetic skills. It is also the basic element of lesson; as it aims at learning a basic skill achieving the direct goal of the lesson (25-56).

Thus, the first hypothesis becomes clear which states that there are statistically significant differences between the pre and post measurements in the level of learning some basic skills in gymnastics for students of control group.

Table (2) shows that there are statistically significant differences between the pre and post measurements in the skillful variables for the experimental group in favor of the post measurement; as table (T) was between 3.25 to 3.95 which is higher than the value of tabled (T).

The researcher attributes these differences to the educational program of the suggested educational modules that has been used by "Ibrahim Ahmed" (2006) (1), " Ahmed Alghamdy" (2008) (5) and "Rehab Hafez" (2007) (10) which agreed about the superiority of the experimental groups because of the educational module program which achieved clear effects in passiveness of different gymnastics skills level according to the goal of each study.

The researcher believes that the educational program of the used educational module led to improving the experimental group as it is prepared perfectly according to students` abilities. Also its exercise were appropriate with the skill needed to learn in gymnastics.

Also these results agreed with "Ali Abdel Mohsen Abdelrahman" (2002)(19) that the educational module style affected positively on learning track and field skills for the second grade students at primary school.

These results also agreed with the result of "Shereef Foaud Algerwany" (2003) (1) study that the educational modules styles has positive effect on learning some defensive skills 
and cognitive achievement for the experimental group.

Those results again agreed with "Ibrahim Nawar" (2006)(1) results which show that there is statistical significant effect of selflearning style (suggested strategy using some selflearning styles together) which are modules and computers program in developing the technical skills and safe skills.

The results also agreed with the results of " Rehab Ahmed Hafez"(2007) (10) study, as the educational module style affects positively on the level Thus, the second hypothesis becomes clear which states that there are statistically significant differences between the pre and post measurements in the level of learning some basic skills in gymnastics for students of experimental group. Table (3) shows that there are statistically significant differences between the two post measurements in the skillful variables for the control and experimental groups in favor of the experimental group; as the calculated (T) is higher than tabled (T).

The researcher attributes this progress for the positive role and the effectiveness of the suggested educational module in the education process in the sport field during designing visual educational programs as an educational mean saving the effort and time. It also helps the learner to understand the basic skills in gymnastics. The researcher took into account attraction factor in transmitting this skill well for the learners. The image of this skill indicates how to perform it correctly. The researcher believes through this study, that modules help the teacher to identify the abilities of students, their suitability for each module and following their behavior and performance during studying the module.

Also these results agree with the results of "Tarek Shokry Alkatan" (2007) (12) which referred that the modules affect positively on the level of basic skills performance in basketball. And the educational modules are more effective on the level of basic skills performance in basketball than the traditional method( explanation\& model performance). This means that the modules are effective; thus the experimental group is better than the control one because it used modules in learning which depend on 
learning perfectly with $70 \%$ in order to pass the module and get another one. This refers to the effectiveness of learning with $50 \%$ as in the traditional system.

The researcher attributed those results that using modules contributes in finding better educational environment where students could be attention for the educational process through encouraging them into the scientific thought and the positive participation in learning according to their abilities. In addition to the logic sequence provided by the module which increases the attention towards the parties of skill.

"Sherif Fouad Algerwany" (2003) (11) assures that the educational module provide every student to learn part of the subject according to his abilities and don't transmit to another part until he prefect the last part.

Thus, the third hypothesis has achieved which states that there are statistically significant differences between the two post measurements in the level of learning some basic skills in gymnastics for students of experimental and control groups in favor of the experimental group of study.

\section{Conclusions:-}

- The educational program of module used has a positive effect in learning the methodical skills in gymnastics for first grade students of primary school.

- using the educational module contributes in decreasing the learning time and reaching at perfection in short time.

- The program of suggested learning module improves the skillful variables more than the school program.

\section{Recommendations:-}

1- ministry of education and who are responsible for preparing the curriculum of physical education should encourage using the educational module within the curriculum.

2- Teachers should apply the educational module during learning different skills.

3-teachers should train on preparing detailed tests in different sides of physical education curriculum and on measuring these tests and analyzing their results.

4- Preparing courses for teachers in order to identify how to use and prepare the reference of the unit to learn the kinetic skills at the primary school.

The references:-

First: The Arabic references

1-Ibrahim Ibrahim Ahmed

Nawar: The effectiveness of the proposed strategy using modules and computerized program in developing the technical and security skills for the teachers at primary schools in the science labs, unpublished Master Thesis, 
Faculty of Education - Kafr elSheikh Branch, Tanta University, 2006.

2. Abu Naga Ahmed Ezz alDin: "Curriculum in Physical Education for heterosexual and properties," Shagaret Aldur library, Mansoura, 2000.

3-Ahmed Ismail Haji: "Education in the past - present - future", Egyptian Renaissance Library Renaissance Library, Cairo, 2002.

4. Ahmed Hadi - Youssef alBadawi: Systematic methods in the education and training of gymnastics, Knowledge House, Cairo, 1997.

5. Ahmed bin Hanash Ahmed al-Ghamdi: "Identifying the effectiveness of using the small educational units ( modules ) on achieving the students of teachers faculties in the curriculum of the basics and programs of physical education," Unpublished Master, Curriculum and Instruction Department, College of Education, Umm Al Qura University, the Ministry of Education Higher, Saudi Arabia, 2008.

6. Adele Saad Shenouda, Samia Farghali Mansour: The artistic gymnastics (concepts and applications), "Forum of Thought for publication, the first edition, Alexandria, 1999.

7. Adele Saad Shenouda, Samia Farghali Mansour: The artistic gymnastics (concepts and applications), "Forum Thought for publication, the first edition, Alexandria, 1999.

8. Gamal al-Din Abdel Atty Mohammed: "programmed learning in physical education and sport, Dar Arab Thought, Cairo, 2008.

9. Hassan Sayed Moawad: "Methods of Teaching in Physical Education, Library of modern Cairo, Cairo, i 3.1999 $\mathrm{m}$.

10. Rehab Ahmed Hafez: "The effect of proposal program using the educational modules on learning some complex motor skills in rhythmic gymnastics for the students of the Faculty of Physical Education in Alexandria " , Ph.D., Faculty of Physical Education for Girls, Alexandria University, 2007.

11. Sharif Fouad Jarwani: The Educational modules and its impact on learning some defensive skills in the field of boxing with students of the Faculty of Physical Education in Tanta, the scientific journal of Physical Education, Science, second edition, Tanta University, 2003.

12. Tariq Shukri Qattan: The impact of using modules on the level of performing basic skills in basketball, Journal of Contemporary Psychology, Minia University, 2007. Assiut Journal For Sport Science Arts 
13. Abdul Hameed Sharaf learning technology in physical education, book center for publishing, Cairo, 2000.

14. Abdel Fattah Lutfi, Esmat Fahmi: Physical Education for the role of male and female teachers, the General Administration of Press princely, Cairo, 1998.

15. Alaa aldin Aliyu Mohammed Mersal Hamad : - Pictorial physical exercise (individual- twins- collectivemini games), the first edition, modern library, Mansoura, 2002.

16- Afaf Abdul Karim: Teaching to learn in physical education and sport, knowledge institution , Alexandria, 1990.

17. Imad Eldin Sayed HasbAllah: "The impact of positive self-model on the level of motor and cognitive achievement among free mobility in the exercise level," Journal of Science and Arts Sports, Volume 20, Issue 3, Faculty of Physical Education for Women, Helwan University, 2004.

18. Ali Ahmed Madkoor: The education curricula, its basics and applications, Dar Arab Thought, Cairo, 1998.

19. Ali Abdel Mohsen AbdelRahman: The impact of using the educational module to learn some of the track and field competitions for second grade students of primary schools at Mina, Ph.D., Faculty of Physical Education, Assiut University, 2002

20. Kamal Abdul Hamid Zaytoon: The educational technology in the age of information and communication, the world of the book, 2nd Floor, Cairo, 2003.

\section{Mohamed Ibrahim Bilal:}

the impact of the use of educational module on the level of some physical and skill variables in football Scientific Conference, Faculty of Physical Education for Boys, Helwan University, 2010.

\section{Mohammed Ibrahim}

Shehata: The basics of learning Gymnastics ", i 1, Dar Arab Thought, Cairo, 2000.

\section{Mohammed Ibrahim}

Shehata:

Learning contemporary gymnastics ", i 1, Dar Arab Thought, Cairo, 2003.

24. Mohammed Ibrahim Shehata: the basics of sports training. Egyptian library, publishing, Alexandria 2006.

25. Mohammed Ibrahim

Shehata: Gymnastics guide, Knowledge House, Alexandria, 1992. 
26. Mohammed Ibrahim

Shehata: Ground gymnastics and horse jumping, technical Printing and Publishing, 1987.

27. Mohammad Hassan Allawi: The psychology of sports training and competitions, the seventh edition, Knowledge House, Cairo, 1992.

28. Mohammed Abdul Ghani

Othman: - Motor learning and sports training, second edition, Dar Pen, Kuwait, 1994.

29. Moussa Ibrahim Fahmy just good: Exercise and presentations, Knowledge House, Cairo, 1994.

30. Nabila Khalifa and others: the scientific and technical foundations of the gymnastics and exercises, Dar Arab Thought, Cairo.

Second: English References:31-Kirchner, G J.Fishburna: Physical Education for school child,: Brown \& Benchmark Lowa, 2003.

32-Rink, J: teaching physical education for learning 'low, New york, 1998.
33- Holliss A.C: "Awrtten program of self instruction for learning the Cartwheel in gymnastics 'M.S in physical Education And recreation, vol.12. 1990.

34- J udith Miller: s cott D ickson: "found a mental Motor skias Intervention programs School of New wrricuim studies University England http: www. htm. Melburne 6) VV 99Victoria Gg pap s pr

Millor, R: why - ro 1999 is science hard to learn, Journal of computers assisted .1991 learning,

-r rannierfosterV \& callahue ng physical education in Teachi elementary school, w.b saundes company philadelaphia london ‘tronoto5 ed., 1973.

37- Xiao,-G research: on the specibicstrengti of gymanstices on the Chinese, sprail, Journol, of Beijing university of Physicaleducation 1998. 